\title{
Pengaruh profitabilitas, firm size, dan good corporate governance untuk menguji manajemen laba
}

\author{
${ }^{1 *}$ Sheli Marselina Br Perangin Angin \\ ${ }^{1}$ Universitas Sarjanawiyata Tamansiswa, Jalan Kusumanegara Yogyakarta 55165 \\ *e-mail korespondensi: shelimarselinabrp499@gmail.com
}

\begin{tabular}{l|l}
\hline \multicolumn{1}{c}{ Keywords } & \multicolumn{1}{c}{ Abstract } \\
\hline \hline $\begin{array}{l}\text { Profitability, Firm } \\
\text { Size, Good }\end{array}$ & This study was conducted with aim of analyzing the affect of Profitability, Firm Size, \\
Corporate & Independent Board of Commissioners and Audit Committee used to test earning \\
Governance, & management. The oil and gas sub-sector company listed on the Indonesia Stock \\
Independent Board & Exchange for the period 2015-2019 were the population of this study. The method \\
of Commissioners, & used is purposive sampling. The Sample of study used by 8 companies. This type of \\
Audit Committee, & research is quantitative with secondary data sources. The analytical technique used \\
Earning & is multiple linear regression analysis. Data processed on SPSS program version \\
Management & 23.0. The results of this study showed that profitability has a significant positive \\
& effect on earning management in oil and gas sub-sector companies. Firm size has a \\
& significant positive effect on earning management in oil and gas sub-sector \\
& companies. The independent board of commissioners has no significant impact on \\
& earning management in oil and gas sub-sector companies. The audit committee has \\
& no effect on earning management in oil and gas sub-sector companies.
\end{tabular}

Kata Kunci

Abstrak

\begin{tabular}{|c|c|}
\hline $\begin{array}{l}\text { Profitabilitas, } \\
\text { Ukuran Perusahaan, } \\
\text { Tata Kelola } \\
\text { Perusahaan, Dewan } \\
\text { Komisaris } \\
\text { Independen, } \\
\text { Komite Audit, } \\
\text { Manajemen Laba }\end{array}$ & $\begin{array}{l}\text { Penelitian ini dilakukan dengan tujuan untuk menganalisis pengaruh Profitabilitas, } \\
\text { Ukuran Perusahaan, Dewan Komisaris Independen dan Komite Audit yang } \\
\text { digunakan untuk menguji manajemen laba. Perusahaan sub sektor migas yang } \\
\text { terdaftar di Bursa Efek Indonesia periode } 2015-2019 \text { menjadi populasi dalam } \\
\text { penelitian ini. Metode yang digunakan adalah purposive sampling. Sampel } \\
\text { penelitian digunakan oleh } 8 \text { perusahaan. Jenis penelitian ini adalah kuantitatif } \\
\text { dengan sumber data sekunder. Teknik analisis yang digunakan adalah analisis } \\
\text { regresi linier berganda. Data diolah pada program SPSS versi } 23.0 \text {. Hasil penelitian } \\
\text { ini menunjukkan bahwa profitabilitas berpengaruh positif signifikan terhadap } \\
\text { manajemen laba pada perusahaan sub sektor migas. Ukuran perusahaan berpengaruh } \\
\text { positif signifikan terhadap manajemen laba pada perusahaan sub sektor migas. } \\
\text { Dewan komisaris independen tidak memberikan pengaruh yang signifikan terhadap } \\
\text { manajemen laba pada perusahaan subsektor migas. Komite audit tidak berpengaruh } \\
\text { terhadap manajemen laba pada perusahaan sub sektor migas. }\end{array}$ \\
\hline
\end{tabular}

\section{PENDAHULUAN}

Perkembangan pasar modal di Indonesia mengharuskan perusahaan untuk memberikan penampilan maksimal terhadap kinerja keuangannya, yang mana dapat diukur dengan menggunakan laporan keuangan. 


\section{Entrepreneurship Bisnis Manajemen Akuntansi (E-BISMA), 1(1), 42-53 \\ Sheli Marselina Br Perangin Angin}

Laporan laba/rugi adalah bagian dari laporan keuangan. Laporan laba/rugi sangatlah penting, sehingga tidak jarang informasi tersebut menjadi target rekayasa para manajer untuk memaksimumkan kepuasannya, sehingga dapat merugikan pihak investor. Perilaku manajemen dalam mengatur laba disebut manajemen laba (earning management) (Amelia \& Hernawati, 2016). Alasan manajer melakukan manajemen laba adalah untuk kepentingan peningkatan kepercayaan investor pada kinerja perusahaan serta menyeimbangkan hubungan dengan kreditor (Panjaitan \& Muslih, 2019), seperti yang dilakukan oleh PT Hanson International Tbk.

Objek penelitian ini adalah perusahaan sub sektor pertambangan minyak dan gas bumi, hal ini dikarenakan perusahaan dapat memberikan kontribusi terhadap perubahan IHSG (Indeks Harga Saham Gabungan) di Bursa Efek Indonesia.

Profitabilitas adalah salah satu dimensi dari kinerja keuangan perusahaan untuk mengatur kemampuan perusahaan dalam pencapaian laba, dilihat dari tingkat pengembalian (return) yang diperoleh perusahaan dari perputaran aset dengan menggunakan beberapa alat ukur yaitu: Gross Profit Margin, Return on Assets, Return on Equity dan Per share Earnings (Bangun, 2019). Untuk penelitian ini, profitabilitas diukur dengan menggunakan Return on Assets.

Selain profitabilitas, firm size juga dapat mempengaruhi manajemen laba. Firm size merupakan perbandingan besar dan kecilnya perusahaan dengan beberapa cara, antara lain: total aset, log size, nilai pasar saham (Amertha et al., 2014).

Menurut teori keagenan, mengatasi masalah ketidakselarasan kepentingan antara prinsipal dan agen dilakukan melalui pengelolaan perusahaan yang baik (Mangkusuryo \& Jati, 2017).

Principles et al. (2020) mendefinisikan good corporate governance adalah sistem pengarahan dan pengendalian perusahaan yang bertujuan untuk menyeimbangkan kekuatan otoritas yang diperlukan oleh perusahaan serta memastikan keberadaan dan akuntabilitasnya yang berkelanjutan kepada para pemangku kepentingan.

Adanya komite audit dan dewan komisaris independen dalam suatu perusahaan efektif dalam pencegahan praktik manajemen laba, karena keberadaan komite audit dan dewan komisaris independen ditujukan untuk melakukan pengawasan kegiatan perusahaan dalam mencapai tujuan perusahaan (Mangkusuryo \& Jati, 2017).

Berdasarkan penjabaran diatas, penelitian yang dilakukan adalah menguji pengaruh profitabilitas, firm size dan good corporate governance kepada manajemen laba perusahaan sub sektor minyak dan gas bumi yang terdaftar di Bursa Efek Indonesia periode 2015-2019.

\section{TEORI DAN HIPOTESIS}

\section{Manajemen laba}

Manajemen laba adalah tindakan manajer dalam peningkatan atau penurunan laba yang digunakan sebagai laporan suatu unit yang merupakan tanggung jawab manajer tanpa mengkaitkan peningkatan ataupun penurunan profitabilitas ekonomi jangka panjang (Herlambang, 2015). Trisnawati et al. (2015) berpendapat beberapa motivasi dalam 


\section{Entrepreneurship Bisnis Manajemen Akuntansi (E-BISMA), 1(1), 42-53 \\ Sheli Marselina Br Perangin Angin}

melakukan manajemen laba, yaitu: (a) bonus plan hypothesis, (b) perjanjian hutang, (c) motivasi politik, (d) motivasi perpajakan, (e) pergantian CEO dan (f) penawaran umum perdana.

\section{Profitabilitas}

Menurut pendapat Hasty \& Herawaty (2017) profitabilitas merupakan rasio untuk menilai kemampuan perusahaan dalam mencari keuntungan. Return on assets (ROA) adalah bentuk dari rasio profitabilitas yang digunakan dalam mengukur kemampuan suatu perusahaan untuk menghasilkan laba selama periode tertentu pada tingkat penjualan, aset, dan modal saham serta mengukur kemampuan perusahaan menghasilkan laba menggunakan total aktiva yang ada setelah biaya-biaya modal dikeluarkan dari analisis (Ayem \& Setyadi, 2019).

Perusahaan yang memiliki laba besar akan mempertahankan labanya pada level tertentu agar dapat memberikan dampak kepercayaan terhadap investor, karena itulah manajemen termotivasi untuk melakukan manajemen laba, agar laba yang dilaporkan tidak berfluktuatif. H1: Profitabilitas berpengaruh positif terhadap manajemen laba pada perusahaan sub sektor pertambangan minyak dan gas bumi yang terdaftar di Bursa Efek Indonesia periode 20152019.

\section{Firm Size}

Firm size berkaitan dengan jumlah sumber daya yang dimiliki oleh perusahaan. Sebuah perusahaan dapat diukur melalui beberapa aspek, total aset, dan jumlah pekerja (Bangun, 2019).

H2: Firm size berpengaruh positif terhadap manajemen laba pada perusahaan sub sektor pertambangan minyak dan gas bumi yang terdaftar di Bursa Efek Indonesia periode 20152019.

\section{Good Corporate Governance}

Good corporate governance merupakan konsep dalam peningkatan kinerja perusahaan yang dapat dilakukan melalui supervisi dan monitoring kinerja manajemen serta menjamin akuntabilitas manajemen terhadap stakeholder berdasarkan pada kerangka peraturan. Konsep good corporate governance diajukan agar tercapai tata kelola perusahaan yang transparan bagi semua pengguna laporan keuangan. (Hasty \& Herawaty, 2017).

Good corporate governance ditandai dengan adanya kepemilikan manajerial, komite audit dan dewan komisaris independen. Adanya komite audit dan dewan komisaris independen efektif dalam mencegah praktik manajemen laba, karena keberadaan komite audit dan dewan komisaris independen ditujukan untuk mengawasi kegiatan perusahaan. (Mangkusuryo \& Jati, 2017).

Dewan komisaris independen adalah anggota komisaris yang tidak memiliki hubungan dengan manajemen, bebas dalam hubungan bisnis dan hubungan lainnya serta dapat 


\section{Entrepreneurship Bisnis Manajemen Akuntansi (E-BISMA), 1(1), 42-53 \\ Sheli Marselina Br Perangin Angin}

bertindak independen atau semata-mata demi kepentingan perusahaan (Amelia \& Hernawati, 2016).

H3: Dewan komisaris independen berpengaruh negatif terhadap manajemen laba pada perusahaan sub sektor pertambangan minyak dan gas bumi yang terdaftar di Bursa Efek Indonesia periode 2015-2019.

Komite audit ditujukan untuk membantu dewan komisaris melakukan fungsi pengawasan terhadap kinerja perusahaan dalam pelaporan keuangan dan melakukan pengendalian yang dapat mengurangi kesempatan terjadinya penyimpangan dalam pengelolaan perusahaan (Ayem \& Setyadi, 2019).

H4: Komite audit berpengaruh negatif terhadap manajemen laba pada perusahaan sub sektor pertambangan minyak dan gas bumi yang terdaftar di Bursa Efek Indonesia periode 20152019.

\section{METODE PENELITIAN}

Penelitian yang digunakan adalah penelitian kuantitatif. Pemilihan sampel dalam penelitian ini adalah purposive sampling, yaitu dengan cara memilih sampel berdasarkan penilaian beberapa karakteristik anggota sampel yang disesuaikan dengan maksud penelitian (Taco \& Ilat, 2016).

Penelitian ini menggunakan data sekunder, yang berasal dari laporan keuangan perusahaan sub sektor pertambangan minyak dan gas bumi yang terdaftar di Bursa Efek Indonesia periode 2015-2019 yang telah diaudit oleh auditor independen dan telah dipublikasikan.

Analisis data yang digunakan adalah analisis statistik deskriptif, uji asumsi klasik, analisis regresi linier berganda dan uji hipotesis, yang mana seluruh uji ini akan dilakukan dengan menggunakan SPSS versi 23.0.

\section{HASIL DAN PEMBAHASAN}

\section{Gambaran Umum Obyek Penelitian}

Penelitian ini menggunakan 8 perusahaan dengan masing-masing perusahaan 5 laporan keuangan dan 5 laporan tahunan mulai dari tahun 2015 hingga 2019. Berikut nama perusahaan yang ditetapkan menjadi sampel:

Tabel 1. Daftar Sampel

\begin{tabular}{|l|l|c|}
\hline No & \multicolumn{1}{|c|}{ Nama Perusahaan } & Kode \\
\hline 1 & Apexindo Pratama DutaTbk & APEX \\
\hline 2 & Ratu Prabu EnergiTbk & ARTI \\
\hline 3 & Elnusa Tbk & ELSA \\
\hline 4 & Energi Mega PersadaTbk & ENRG \\
\hline 5 & Surya Esa PerkasaTbk & ESSA \\
\hline 6 & Medco Energi InternasionalTbk & MEDC \\
\hline 7 & Mitra Investindo Tbk & MITI \\
\hline 8 & Radiant Utama Interinsco Tbk & RUIS \\
\hline
\end{tabular}




\section{Entrepreneurship Bisnis Manajemen Akuntansi (E-BISMA), 1(1), 42-53 \\ Sheli Marselina Br Perangin Angin}

\section{Uji Analisis Statistik Deskriptif}

Tabel 2. Analisis Statistik Deskriptif

Descriptive Statistics

\begin{tabular}{|l|l|r|r|r|r|}
\hline & N & Minimum & Maximum & Mean & Std. Deviation \\
\hline X1 & 40 & -1.538 & .086 & -.08163 & .288034 \\
X2 & 40 & 24.769 & 32.053 & 29.0963 & 1.72143 \\
X3 & 40 & .250 & .667 & .41868 & .101969 \\
X4 & 40 & 2 & 4 & 2.90 & .379 \\
Y & 40 & -.076 & .024 & -.00930 & .021013 \\
Valid N (listwise) & 40 & & & & \\
\hline
\end{tabular}

Berdasarkan tabel diatas diketahui bahwa penelitian ini memiliki 40 jumlah sampel disetiap variabelnya. Profitabilitas diukur menggunakan return on asset (X1) menunjukkan -1,538 sebagai nilai minimum dan 0,86 sebagai nilai maksimum serta nilai rata-rata sebesar -0,08163 dengan standar deviasi sebesar 0,288034. Firm size (X2) memiliki nilai minimum sebesar 24,769 dan nilai maksimum sebesar 32,053 serta nilai rata-rata sebesar 29,09633 dengan standar deviasi 1,721432. Dewan komisaris independen (X3) dan komite audit (X4) menunjukkan bahwa masing-masing nilai minimumnya adalah 0,250 dan 2, sedangkan nilai maksimumnya masing-masing adalah 0,667 dan 4. Dewan komisaris independen (X3) memiliki nilai rata-rata sebesar 0,41868 dengan standar deviasi 0,101969, sementara komite audit (X4) memiliki nilai rata-rata sebesar 2,90 dengan standar deviasi 0,379.

Manajemen laba adalah variabel dependen yang menunjukkan nilai rata-rata sebesar 0,00930 dengan standar deviasi sebesar 0,21013 serta memiliki nilai minimum -0,076 dan nilai maksimum sebesar 0,024 .

\section{Uji Asumsi Klasik \\ Uji Normalitas}

Tabel 3. Hasil Uji Normalitas

One-Sample Kolmogorov-Smirnov Test

\begin{tabular}{|ll|r|}
\hline & & Unstandardized Residual \\
\hline$N$ & & 40 \\
Normal Parameters ${ }^{a, b}$ & Mean & .0000000 \\
& Std. Deviation & .01310657 \\
Most Extreme Differences & Absolute & .092 \\
& Positive & .069 \\
& Negative & -.092 \\
Test Statistic & & .092 \\
Asymp. Sig. (2-tailed) & & $.200^{\mathrm{c}, \mathrm{d}}$ \\
\hline
\end{tabular}

a. Test distribution is Normal.

b. Calculated from data.

c. Lilliefors Significance Correction.

a. This is a lower bound of the true significance. 
Hasil uji normalitas menunjukkan bahwa hasil Asymp. Signifikansi (2-tailed) sebesar 0,200 . Nilai signifikansi $>0,05$, artinya data dalam penelitian ini terdistribusi normal.

\section{Uji Multikolinearitas}

Tabel 4. Hasil Uji Multikolinearitas

\begin{tabular}{|c|c|c|c|c|c|c|c|c|}
\hline \multicolumn{9}{|c|}{ Coefficients ${ }^{a}$} \\
\hline & \multirow{2}{*}{ Model } & \multicolumn{2}{|c|}{$\begin{array}{c}\text { Unstandardized } \\
\text { Coefficients } \\
\end{array}$} & \multirow{2}{*}{$\begin{array}{c}\begin{array}{c}\text { Standardized } \\
\text { Coefficients }\end{array} \\
\text { Beta } \\
\end{array}$} & \multirow[t]{2}{*}{$T$} & \multirow[t]{2}{*}{ Sig. } & \multicolumn{2}{|c|}{ Collinearity Statistics } \\
\hline & & $B$ & Std. Error & & & & Tolerance & $V I F$ \\
\hline \multirow[t]{5}{*}{1} & (Constant) & -.229 & .043 & & -5.301 & .000 & & \\
\hline & $\mathrm{X} 1$ & .020 & .009 & .270 & 2.244 & .031 & .769 & 1.300 \\
\hline & $\mathrm{X} 2$ & .008 & .002 & .624 & 5.019 & .000 & .720 & 1.390 \\
\hline & $\mathrm{X} 3$ & -.006 & .023 & -.027 & -.249 & .805 & .927 & 1.079 \\
\hline & $\mathrm{X} 4$ & .001 & .006 & .010 & .083 & 934 & .811 & 1.233 \\
\hline
\end{tabular}

a. Dependent Variable: Y

Berdasarkan hasil pengujian multikolinearitas diatas, dapat dilihat nilai tolerance dan VIF untuk semua variabel. Tolerance untuk profitabilitas sebagai variabel pertama yang diukur dengan menggunakan return on asset (X1) adalah 0,769, firm size (X2) sebesar 0,720 , dewan komisaris independen (X3) untuk mengukur good corporate governance sebesar 0,927 dan komite audit (X4) sebesar 0,811. Masing-masing nilai tolerance tersebut memiliki nilai lebih besar dari 0,10. Sedangkan untuk nilai VIF, return on asset (X1) memiliki nilai sebesar 1,300, firm size (X2) memiliki nilai sebesar 1,390, dewan komisaris independen (X3) memiliki nilai sebesar 1,079 dan komite audit (X4) memiliki nilai sebesar 1,233. VIF keempat variabel $<10,00$, maka disimpulkan bahwa tidak terjadi multikolinearitas.

\section{Uji Heteroskedastisitas}

Tabel 5. Hasil Uji Glesjer

\begin{tabular}{|c|c|c|c|c|c|}
\hline \multicolumn{6}{|c|}{ Coefficients $^{a}$} \\
\hline \multirow{2}{*}{ Model } & \multicolumn{2}{|c|}{ Unstandardized Coefficients } & $\begin{array}{c}\text { Standardized } \\
\text { Coefficients }\end{array}$ & \multirow[t]{2}{*}{$\mathrm{T}$} & \multirow{2}{*}{ Sig. } \\
\hline & $\mathrm{B}$ & Std. Error & Beta & & \\
\hline $1 \quad$ (Constant $)$ & .033 & .027 & & 1.202 & .237 \\
\hline $\mathrm{X} 1$ & .006 & .006 & .197 & 1.046 & .303 \\
\hline $\mathrm{X} 2$ & -.001 & .001 & -.148 & -.762 & .451 \\
\hline $\mathrm{X} 3$ & -.008 & .014 & -.092 & -.540 & .593 \\
\hline $\mathrm{X} 4$ & .001 & .004 & .032 & .174 & .863 \\
\hline
\end{tabular}

a. Dependent Variable: Abs_Res 
Berdasarkan tabel diatas, diketahui bahwa nilai signifikansi return on asset (X1) adalah 0,303, firm size (X2) adalah 0,451, dewan komisaris independen (X3) adalah 0,593 dan komite audit (X4) adalah 0,863. Seluruh nilai signifikansi variabel independen dengan abs residual $>0,05$, maka disimpulkan tidak terjadi masalah heterokedastisitas.

\section{Uji Autokorelasi}

Tabel 6. Hasil Uji Autokorelasi Model Summary ${ }^{b}$

\begin{tabular}{|l|r|r|r|r|c|}
\hline Model & $R$ & R Square & Adjusted R Square & $\begin{array}{c}\text { Std. Error of the } \\
\text { Estimate }\end{array}$ & $\begin{array}{c}\text { Durbin- } \\
\text { Watson }\end{array}$ \\
\hline 1 & $.781^{\mathrm{a}}$ & .611 & .566 & .013840 & 1.319 \\
\hline
\end{tabular}

a. Predictors: (Constant), X4, X3, X1, X2

b. Dependent Variable: $Y$

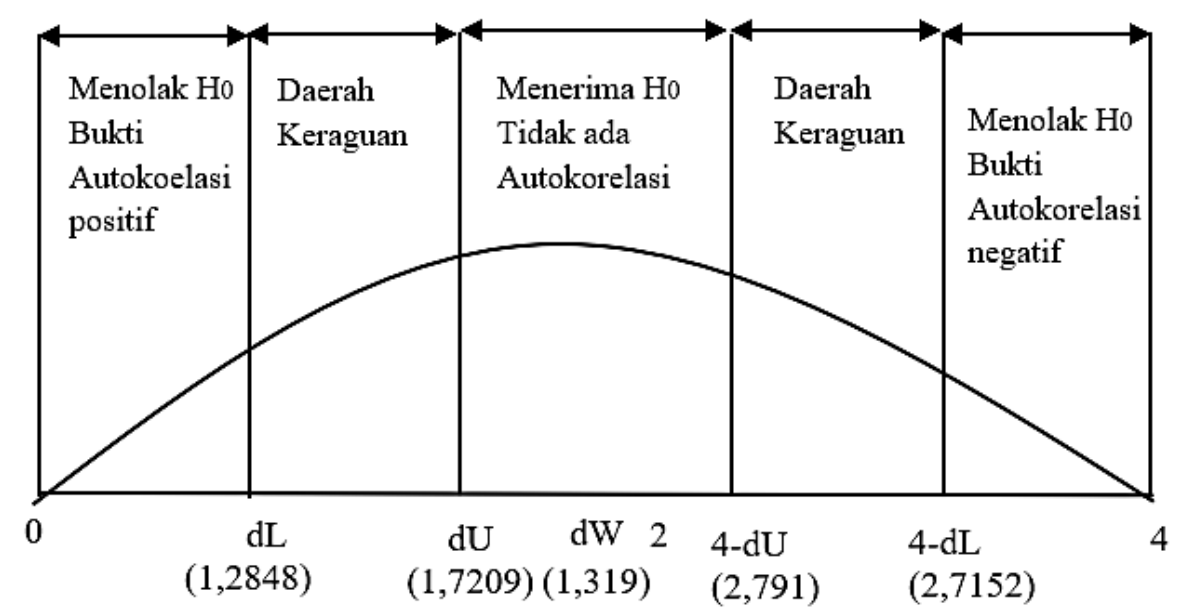

Gambar 1. Durbin Watson

Hasil pengujian autokorelasi ini dengan signifikansi sebesar 5\%, jumlah sampel yang digunakan sebanyak 40, serta jumlah variabel bebas sebanyak 4. Dapat dilihat bahwa nilai Durbin Watson (dW) sebesar 1,319, nilai dL sebesar 1,2848, nilai dU sebesar 1,7209 dan nilai 4-dL sebesar 2,7152 serta nilai 4-dU sebesar 2,791, sehingga memperoleh hasil $\mathrm{dU}<\mathrm{dW}<4-\mathrm{dU}$. Berdasarkan hasil tersebut, dapat disimpulkan bahwa model regresi dalam penelitian ini bebas dari autokorelasi. 
Entrepreneurship Bisnis Manajemen Akuntansi (E-BISMA), 1(1), 42-53

Sheli Marselina Br Perangin Angin

\section{Uji Regresi Linier Berganda}

Tabel 7. Hasil Uji Regresi Linier Berganda

Coefficients $^{a}$

\begin{tabular}{|ll|r|r|r|r|r|}
\hline \multirow{2}{*}{ Model } & \multicolumn{2}{|c|}{$\begin{array}{c}\text { Standardized } \\
\text { Coefficients }\end{array}$} & \multirow{2}{*}{$t$} & Sig. \\
\cline { 2 - 6 } & \multicolumn{1}{|c|}{ Unstandardized Coefficients } & Beta & & \\
\hline 1 & (Constant) & -.229 & .043 & & -5.301 & .000 \\
& X1 & .020 & .009 & .270 & 2.244 & .031 \\
X2 & .008 & .002 & .624 & 5.019 & .000 \\
X3 & -.006 & .023 & -.027 & -.249 & .805 \\
X4 & .001 & .006 & .010 & .083 & .934 \\
\hline
\end{tabular}

a. Dependent Variable: $\mathrm{Y}$

Sumber: output SPSS 23.0, data sekunder diolah, 2020

Penjelasan untuk persamaan regresi diatas adalah sebagai berikut:

a. Konstanta sebesar -0,229 menunjukkan bahwa apabila nilai variabel return on asset (X1), firm size (X2), dewan komisaris independen (X3) dan komite audit (X4) adalah nol, maka manajemen laba akan memiliki nilai sebesar -0,229.

b. Koefisien regresi untuk variabel return on asset (X1) sebesar $+0,020$ menunjukkan hasil terdapat pengaruh yang signifikan antara variabel return on asset (X1) terhadap manajemen laba, artinya setiap return on asset (X1) mengalami kenaikan sebesar satu satuan, maka manajemen laba mengalami kenaikan sebesar 0,020.

c. Koefisien regresi untuk variabel firm size (X2) sebesar $+0,008$ menunjukkan hasil terdapat pengaruh yang signifikan antara variabel firm size (X2) terhadap manajemen laba, artinya apabila firm size (X2) mengalami kenaikan satu satuan, maka manajemen laba mengalami kenaikan sebesar 0,008.

d. Koefisien regresi untuk variabel dewan komisaris independen (X3) sebesar -0,006 menunjukkan hasil tidak terdapat pengaruh variabel dewan komisaris independen (X3) terhadap manajemen laba, artinya apabila dewan komisaris independen (X3) mengalami kenaikan satu satuan, maka manajemen laba mengalami penurunan sebesar 0,006

e. Koefisien regresi untuk variabel komite audit (X4) sebesar $+0,001$ menunjukkan hasil tidak terdapat pengaruh variabel komite audit (X4) terhadap manajemen laba, artinya apabila komite audit (X4) mengalami kenaikan satu satuan, maka manajemen laba akan mengalami kenaikan sebesar 0,001 . 
Entrepreneurship Bisnis Manajemen Akuntansi (E-BISMA), 1(1), 42-53

Sheli Marselina Br Perangin Angin

\section{Uji Hipotesis \\ Pengujian Hipotesis Secara Parsial (Uji t)}

Tabel 8. Hasil Uji Parsial t

\begin{tabular}{|c|c|c|c|c|c|}
\hline \multicolumn{6}{|c|}{ Coefficients } \\
\hline \multirow[t]{2}{*}{ Model } & \multicolumn{2}{|c|}{ Unstandardized Coefficients } & $\begin{array}{l}\text { Standardized } \\
\text { Coefficients }\end{array}$ & \multirow[t]{2}{*}{$t$} & \multirow[t]{2}{*}{ Sig. } \\
\hline & $B$ & Std. Error & Beta & & \\
\hline $1 \quad$ (Constant) & -.229 & .043 & & -5.301 & .000 \\
\hline $\mathrm{X} 1$ & .020 & .009 & .270 & 2.244 & .031 \\
\hline $\mathrm{X} 2$ & .008 & .002 & .624 & 5.019 & .000 \\
\hline $\mathrm{X} 3$ & -.006 & .023 & -.027 & -.249 & .805 \\
\hline $\mathrm{X} 4$ & .001 & .006 & .010 & .083 & .934 \\
\hline
\end{tabular}

a. Dependent Variable: $\mathrm{Y}$

Berdasarkan tabel diatas, dapat dilihat ada atau tidaknya pengaruh variabel $\mathrm{X}$ terhadap variabel Y secara individu dengan melihat ttabel pada tingkat signifikansi 0,05 (satu arah) dan nilai kolom df.

Berdasarkan perhitungan tersebut diperoleh nilai ttabel sebesar 2,03011. Sedangkan, thitung pada return on asset (X1) adalah 2,244 > 2,03011. Firm size (X2) menunjukkan thitung sebesar 5,019>2,03011. Dewan komisaris independen (X3) menunjukkan thitung sebesar $0,249<2,03011$ dan komite audit (X4) menunjukkan nilai thitung sebesar 0,083 < 2,03011.

Nilai signifikansi untuk variabel return on asset (X1) adalah $0,000<0,05$, sedangkan firm size (X2) menunjukkan nilai signifikansi sebesar 0,031 $<0,05$. Dewan komisaris independen (X3) menunjukkan nilai signifikansi sebesar 0,805 >0,05 dan komite audit (X4) menunjukkan nilai signifikansi sebesar $0,934>0,05$.

Uji Kelayakan Model (Uji F)

Tabel 9. Hasil Uji F

ANOVA $^{\mathrm{a}}$

\begin{tabular}{|c|c|c|c|c|c|}
\hline Model & Sum of Squares & $D f$ & Mean Square & $F$ & Sig. \\
\hline 1 Regression & .011 & 4 & .003 & 13.726 & $.000^{\mathrm{b}}$ \\
\hline Residual & .007 & 35 & .000 & & \\
\hline Total & .017 & 39 & & & \\
\hline
\end{tabular}

a. Dependent Variable: $Y$

b. Predictors: (Constant), X4, X3, X1, X2

Berdasarkan tabel hasil pengujian diatas, diketahui nilai Fhitung sebesar 13,726 dan nilai signifikansi sebesar 0,000 $<0,05$, sehingga nilai Fhitung yaitu 0,708 2,63.

Hasil pengujian ini berarti seluruh variabel berpengaruh signifikan. Hipotesis 5 diterima (H5 diterima). 


\section{Uji koefisien Determinasi $\left(\mathbf{R}^{2}\right)$}

Tabel 10. Hasil Uji Koefisien Determinasi ( $\left.\mathrm{R}^{\mathbf{2}}\right)$

\begin{tabular}{|c|c|c|c|c|}
\hline \multicolumn{5}{|c|}{ Model Summary ${ }^{b}$} \\
\hline Model & $R$ & $R$ Square & Adjusted $R$ Square & $\begin{array}{l}\text { Std. Error of the } \\
\text { Estimate }\end{array}$ \\
\hline 1 & $.781^{\mathrm{a}}$ & .611 & .566 & .013840 \\
\hline
\end{tabular}

a. Predictors: (Constant), X4, X3, X1, X2

b. Dependent Variable: $\mathrm{Y}$

Nilai Adjusted $R$-squared sebesar 0,566, artinya variabel independen mampu menjelaskan variabel dependen sebesar $56,6 \%$ sedangkan sisanya dijelaskan oleh variabel diluar model dalam penelitian ini.

\section{Pengaruh Profitabilitas (X1) Terhadap Manajemen Laba (Y)}

Hasil pengujian hipotesis pada variabel ini menunjukkan bahwa profitabilitas (X1) berpengaruh signifikan terhadap manajemen laba. Hal ini terlihat pada tabel 8 yang menunjukkan bahwa ROA (X1) memperoleh nilai thitung sebesar 2,244 > 2,03011 dengan nilai signifikansi $0,031<0,05$ dengan nilai beta sebesar 0,020, dengan demikian hipotesis 1 diterima (H1 diterima). Hasil penelitian ini sesuai dengan penelitian yang dilakukan oleh Purnama (2017), Selviani (2017), (Giovani (2017) dan Fitri et al. (2018) yang menyatakan bahwa variabel profitabilitas dengan proksi Return on Assets (X1) memiliki hubungan positif terhadap manajemen laba.

\section{Pengaruh Firm Size (X2) Terhadap Manajemen Laba (Y)}

Hasil uji hipotesis $2(\mathrm{H} 2)$ menunjukkan bahwa firm size (X2) berpengaruh positif terhadap manajemen laba. Hal ini dapat dilihat dari uji t pada tabel 8 yang mana firm size (X2) menunjukkan nilai thitung sebesar 5,019>2,03011 dengan nilai signifikansi 0,000< 0,05 serta nilai beta sebesar 0,008. Dapat disimpulkan bahwa hipotesis $2(\mathrm{H} 2)$ diterima. Hasil ini diperkuat dengan penelitian sebelumnya, yaitu Amelia \& Hernawati (2016) yang menyatakan bahwa firm size (X2) berpengaruh signifikan terhadap manajemen laba, begitu pun secara parsial.

\section{Pengaruh Dewan Komisaris Independen (X3) Terhadap Manajemen Laba (Y)}

Hasil uji parsial (uji t) antara dewan komisaris independen (X3) terhadap manajemen laba adalah thitung sebesar $-0,249<2,03011$ dengan nilai signifikansi sebesar 0,805>0,05, dapat disimpulkan bahwa hipotesis 3 (H3) ditolak, yang artinya dewan komisaris independen (X3) tidak memiliki hubungan signifikan terhadap manajemen laba. 


\section{Entrepreneurship Bisnis Manajemen Akuntansi (E-BISMA), 1(1), 42-53 \\ Sheli Marselina Br Perangin Angin}

\section{Pengaruh Komite Audit (X4) Terhadap Manajemen Laba (Y)}

Hasil uji parsial (uji t) antara komite audit (X4) terhadap manajemen laba adalah thitung sebesar 0,083 2,03011 dengan nilai signifikansi sebesar 0,934>0,05, dapat disimpulkan bahwa hipotesis $4(\mathrm{H} 4)$ ditolak, yang artinya komite audit tidak memiliki hubungan signifikan terhadap manajemen laba.

\section{KESIMPULAN DAN SARAN}

Kesimpulan penelitian ini adalah profitabilitas yang diukur dengan menggunakan return on asset berpengaruh positif signifikan terhadap manajemen laba. Firm size memiliki pengaruh yang positif signifikan terhadap manajemen laba. Dewan komisaris independen tidak berpengaruh untuk menguji manajemen laba. Komite audit tidak berpengaruh untuk menguji manajemen laba.

Saran untuk investor dan calon investor, diharapkan lebih teliti dalam menerima informasi serta berhati-hati dan bijak dalam mengambil keputusan investasi. Sedangkan untuk perusahaan, seharusnya lebih efektif dan efisien dalam menyajikan informasi yang lebih lengkap seperti laporan keuangan sehingga investor atau pihak eksternal perusahaan dapat mengetahui kondisi perusahaan yang sebenarnya.

\section{DAFTAR PUSTAKA}

Amelia, W., \& Hernawati, E. (2016). Pengaruh Komisaris Independen, Ukuran Perusahaan, Dan Profitabilitas Terhadap Manajemen Laba. NeO Bis, 10(1), 62-77. Diakses dari http://journal.trunojoyo.ac.id/neo-bis/article/view/1584

Ayem, S., \& Setyadi, A. (2019). Pengaruh Profitabilitas, Ukuran Perusahaan, Komite Audit Dan Capital Intensity Terhadap Agresivitas Pajak. Jurnal Akuntansi Pajak Universitas Sarjanawiyata Tamansiswa, 1(2), 228-241. Diakses dari https://doi.org/10.24964/japd.v1i1.905

Bangun, N. (2019). The Effect Of Earning Management, Profitability, And Firm Sizeon Audited Financial Statement Timeliness. International Journal of Innovative Science and Research Technology, 4(7).

Fitri, A. (2018). Pengaruh GCG, Leverage dan Profitabilitas terhadap Manajemen Laba dengan Ukuran Perusahaan sebagai Variabel Moderating pada Perusahaan Perbankan yang terdaftar di Bursa Efek Indonesia dari Tahun 2012-2016. 1-115.

Giovani, M. (2017). Pengaruh Struktur Kepemilikan, Tata Kelola Perusahaan Dan Karakteristik Perusahaan Terhadap Manajemen Laba. Jurnal Akuntansi Bisnis, 15(2), 290-306.

Hasty, A. D., \& Herawaty, V. (2017). Pengaruh Struktur Kepemilikan, Leverage, Profitabilitas Dan Kebijakan Dividen Terhadap Manajemen Laba Dengan Kualitas Audit Sebagai Variabel Moderasi. Media Riset Akuntansi, Auditing \& Informasi, 17(1), 1. Diakses dari https://doi.org/10.25105/mraai.v17i1.2023

Herlambang, S. (2015). Pengaruh Financial Distress, Risiko Litigasi Dan Pengungkapan Corporate Social Responsibility Terhadap Manajemen Laba (Studi Empiris Pada Perusahaan Manufaktur Yang Terdaftar Di Bursa Efek Indonesia Periode 2014-2016). 1 (Vol. 14, Issue 1). 
Mangkusuryo, Y., \& Jati, A. W. (2017). Pengaruh Mekanisme Good Corporate Governance Terhadap Manajemen Laba. Jurnal Reviu Akuntansi Dan Keuangan, 7(2), 1067. Diakses dari https://doi.org/10.22219/jrak.v7i2.20

Panjaitan, D. K., \& Muslih, M. (2019). Manajemen Laba : Ukuran Perusahaan, Kepemilikan Manajerial Dan Kompensasi Bonus. Jurnal ASET (Akuntansi Riset), 11(1), 1-20. Diakses dari https://doi.org/10.17509/jaset.v11i1.15726

Principles, F., Good, I. N., \& Governance, C. (2020). Fairness Principles In Good Corporate Governance. International Journal of Multi Science, 1(1), 29-35.

Purnama, D. (2017). Pengaruh Profitabilitas, Leverage, Ukuran Perusahaan, Kepemilikan Institusional Dan Kepemilikan Manajerial Terhadap Manajemen Laba. Jurnal Riset Keuangan Dan Akuntansi, 3(1), 1-14. Diakses dari https://doi.org/10.25134/jrka.v3i1.676

Selviani, A. H. (2017). Pengaruh Profitabilitas, Leverage Dan Ukuran Perusahaan Terhadap Manajemen Laba (Studi Empiris Pada Perusahaan Manufaktur Yang Terdaftar Di Bursa Efek Indonesia Tahun 2014-2016). Skripsi, 1-142.

Taco, C., \& Ilat, V. (2016). Pengaruh Earning Power, Komisaris Independen, Dewan Direksi, Komite Audit Dan Ukuran Perusahaan Terhadap Manajemen Laba Pada Perusahaan Manufaktur Yang Terdaftar Di Bursa Efek Indonesia. Jurnal Emba: Jurnal Riset Ekonomi, Manajemen, Bisnis Dan Akuntansi, 4(4), 873-884.

Trisnawati, R., Wiyadi, \& Nugraheni, D. (2015). The Analysis of Information Asymmetry, Profitability, and Deferred Tax Expense on Integrated Earning Management. South East Asia Journal of Contemporary Business, Economics and Law, 7(1), 17-24. 